\title{
Interdisciplinary Perspectives on the Study of Vital Urban Communities
}

\section{Jolita Sinkienė, Eglė Gaulė, Jurgita Bruneckienė, Kęstutis Zaleckis, Thomas A. Bryer, Evaldas Ramanauskas}

\author{
Kaunas University of Technology \\ A. Mickevičiaus g. 37, LT-44240, Kaunas \\ cross $^{\text {ref }} \underline{\text { http://dx.doi.org/10.5755/j01.ppaa.16.1.18010 }}$
}

\begin{abstract}
Success of city development depends not only on its political or economic power, level of infrastructure or favorable geographic location. The key factor of success is people living in the city and their ability to collectively and proactively respond to challenges that 21 st century cities are facing. In democratic societies local communities of cities are the most important cells of their structure as they facilitate or impede a sustainable and balanced local development. Although the term of (urban) community vitality is becoming more popular in political agendas and academic research, still there is a lack of consistent and scientifically-based definition of this concept and its research methodology. This article justifies the relevance of the urban community vitality for city development, reviews interpretations of the content of this concept from different sciences perspective and proposes an interdisciplinary definition. This article presents the initial results of a broader research, which aim was to create a methodology for identification and analysis of vitality of urban communities.
\end{abstract}

Keywords: urban development, urban community, community vitality.

Raktažodžiai: miesto vystymasis, miesto bendruomenè, bendruomenés gyvybingumas.

\section{Introduction}

Modern society is predominantly urban. Cities are the main engines of local, regional and national socio-economic growth. Contemporary cities are participants of intense global competition for urban resources, which are vital for its successful functioning. In order to succeed in the global marketplace a city first of all must effectively mobilize and use its internal capital. In this context the major source of urban competitiveness is local people - both individuals and groups (organizations). In modern democratic society people are free to choose the location that meets their 
needs best. Cities where individuals find the solutions to their daily challenges and enjoy the desired level of freedom are the winners and experience high levels of social and economic development.

The main elements of social structure of any city are its local communities; they are where the most important and most dynamic urban changes take place. To achieve a successful and sustainable city development it is important to assure a balanced and healthy development of its local communities. When urban conditions are right people can be inspired to act creatively in their closest environment and solve complex problems that seem unmanageable at first sight. The task of local and national leaders is to create the sense of empowerment in citizens and to strengthen their will, motivation and confidence.

Strategic policy documents of the EU $[15,8]$ and Lithuania promote the creation of inclusive, energetic, accessible urban communities. The Lithuanian progress strategy "Lithuania 2030" and the National Progress Program "Lithuanian 2020" see local communities as most important contributors to the success of the development of the nation: "we are at the beginning of this work; today strong, active, participating in the decision-making local communities is still an aspiration; good intentions and declarations are not enough for communities to function; individuals should be willing to participate in community activities, to be active in decision-making, and, most importantly, feel real powers to address local issues" [30]. Vital communities are the basis for strong local government and state [26].

But: how to transform sound political slogans into functional strategies for action? Who should foster the activity of local communities in urban areas and how? How community vitality should be maintained and supported? The answer is still a serious challenge for both scholars and practitioners.

Although literature analysis indicates the growing interest of scholars representing different fields of science (mainly sociology and urban planning) to address the issue of (urban) community vitality, still the concept of "urban community vitality" lacks stronger academic focus and clear overall definition.

The team of researchers from Kaunas University of Technology, representing social sciences (Public Management, Economics) and Arts (Architecture and Urban Development) in 2016 implemented an interdisciplinary research aimed to provide a definition of vital urban community and to develop a methodology to analyze the vitality of urban community. The research was based on an interdisciplinary approach to understanding how different social, economic and spatial processes (issues and potentials) come together in shaping the vitality of urban community.

The objectives of this paper: a) to present a conceptual framework for the urban community vitality domain b) to specify approaches of social and urban planning sciences towards the concept of urban community vitality. Research methods: literature studies, document analysis, statistical data analysis, Space Syntax.

\section{Vitality of Urban Communities: Why Important?}

Cities are the incubators for innovation, the "laboratories of our future" [33]. 
They have the power to innovate, generate wealth, enhance quality of life and accommodate more people within a smaller carbon footprint [42]. Countries that are highly urbanized tend to have higher incomes, more stable economies, stronger institutions and are better able to withstand the volatility of the global economy [23]. Cities are increasingly important in the context of a globalized knowledge-based economy and climate change.

Cities are active participants in a highly dynamic global marketplace. Individuals and organizations make free choices for the location to live, to work, to invest, to recreate. In order to stay competitive cities have to offer attractive conditions for people and organizations to perform these functions. They should offer safe, vibrant, diverse, open, energetic environments. Only those who succeed in the global marketplace can maintain a good quality of life for its members. Vitality of cities does not emerge automatically. Instead, all social groups (residents, private, public and non-governmental organizations, visitors, all levels of government) interested in wellbeing of the city make a big difference.

Some local communities rank among the highest in national measurements of quality of life, economic development, government transparency, education, or health. At the same time they report high levels of social support, extending assistance to family, neighbors and friends, a strong sense of belonging to their local communities [35]. There, as a rule, levels of crime are down - an indicator of strong community relationships. Yet other local communities report intensive out migration of high-skilled residents and businesses, and high levels of discrimination based on race, religion, culture, and language; local economies face downturns or other negative socio-economic trends. Relationships in family/neighborhood/community have a direct impact on these scenarios.

In recent decades increasing attention has been paid to the question what constitutes a functional [29] community. Why some communities are more successful than others? What are the reasons behind the "success" of one and "failure" of another? Although states provide citizens with social welfare and equal opportunities, it is undisputed that the well-being of citizens is ensured more effectively if members of local communities themselves participate in problem solving processes. Local communities can cooperate and challenge local authorities, require quality services and, most importantly, solve the problems of the local population themselves. Only with a common aim, clearly knowing what they need and acting together, communities remain strong and secure [43].

For a clearer analysis of urban vitality concept, it is important to explain the general model of a city structure. Cities are complex social-spatial systems consisting of several interrelated domains. In different research contexts these domains are named differently: urban "software" and "hardware"; urban "social sphere" (through their life time all individuals are constantly involved in interrelated social, government and economic activities to achieve their general life aim - well-being/ higher quality of life - QoL) and "space" (consisting of built and natural environment); urban "content" and "form"; "people" and "space". 
"software"/ people / content...

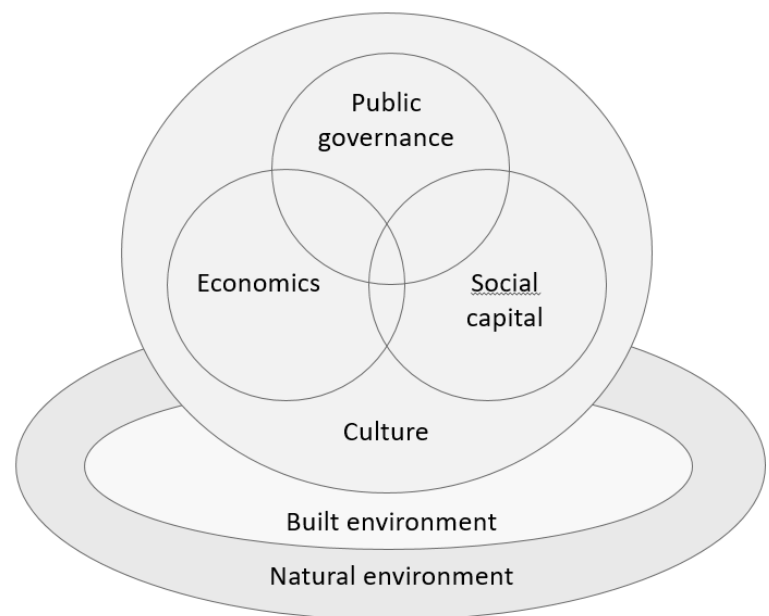

"hardware"/ space / form...

Fig. 1. Subsystems of a city: natural environment, built environment, economics, social capital, public governance

Source: created by authors.

Today we know how to build sophisticated transport networks, smart buildings, and speedy communication technologies. However, the focus of urban policymakers should move from "hardware" to "software" - the people. They must see a city as a living organism consisting of many individual cells - individuals - grouped into smaller or larger units - organizations, communities, aiming to achieve a healthy, sustainable individual and social well-being. According to Landry [21], today the major source of urban competitiveness is one crucial resource: people. The author argues that human motivations, imagination, creativity replace the importance of natural resources, location, and access to markets or infrastructure - as urban resources. Harnessing these qualities and allowing people to express themselves in initiatives and projects is what urban vitality is about. It is important to remember that human beings are profoundly shaped by the environment within which they live, work, recreate and circulate.

Vitality of local community can make the difference between success and failure of the city. Vital communities solve complex problems of their members locally, using own internal or attracting external resources more effectively: less time on decision making, more attention to the process, less public budget resources are required. Active and well organized local communities target their actions in time and where they are needed most. The need for involvement of higher levels of government is much lower. Also, active and well-functioning urban communities create favorable, supporting environment for individual or group initiatives and innovations. They are the incubators/labs where new solutions to the local problems can be tested and then - if successful - be transferred to other parts of the city or beyond. 


\section{Urban Community}

In order to come to a definition of "vital urban community", it is necessary to define each element constituting the term.

Community: The definition of "community" is usually taken for granted but not truly understood. If we ask a group of people this question, we will see that their definitions vary widely. Neither scholars nor the general public have developed a shared conception of what community means: "community is something almost everyone feels strongly about, but few can agree upon what it is" [6]. Analysis of various definitions of 'community' indicates one common element: people . The most general (but receiving much criticism, too) definition is: "community is a whole of individuals and organizations sharing a common aim".

For sociologists community is a particular form of social organization based on small groups or a spatially bounded locality, such as neighborhood. In political science community refers to a group of individuals, where the emphasis is on decision making, self-governance, civil society and collective identity. From public governance perspective community is seen as a mechanism of response to social and political challenges: collaborative governance brings public and private stakeholders together in collective forums with public agencies to engage in consensus-oriented decision making. Critical variables that will influence whether or not this mode of governance will produce successful collaboration: prior history of conflict or cooperation, the incentives for stakeholders to participate, power and resources imbalances, leadership, and institutional design [4]. The process entails building trust between participants; developing shared understanding of the problem via deliberation and negotiation; and developing the resources, capacity, and leadership to support engagement. For economists community is important as a creator and user of shared value, as a key actor in local economic development processes, and a socialterritorial system where resources are exchanged. Urban planners define community as a "social group sharing the similar culture, values, rules and territory".

Clearly, there are different ways of approaching the community question. These include communities based upon close geographical proximity [24;37], communities as localized social systems binding social groups and institutions [3], or communities as forms of communion based on a common identity or set of believes and practices. All, however, appear united around attempts to understand 'belonging'.

The typology of communities is very diverse. Communities can be: open (actively interacting with external environment) or closed (only members of the community interact with each other; external communication is limited); real (communication is face-to-face) or virtual (acting on the ICT-based platforms); institutionalized/formal (associations, societies, ...) or informal (gamer clubs, parents gatherings, other) etc. Dealing with the notion of vitality, it is important to define what type of community it refers to.

There are two general ways to classify communities: by its territory/place (country, region, city, village, neighborhood, home, ... ) and by interest (a gathering of people assembled around a topic of common interest: food, pets, political views, 
religion, age, ...). Very often these two ways of approaching community overlap. Territorial community areas usually have clearly established limits established on the basis of political decision (local government, Planning Commission, other). The general aim for establishing territorial communities is to seek for the individual and social wellbeing of its members more effectively and efficiently.

The Lithuania Law on Self-governance [22] foresees the following types and definition of local communities:

- "Municipal community" - means permanent residents of a municipality related by common public needs, interests and local government legal relations to the municipal council and other municipal entities performing public administration functions.

- "Local community" - means residents of a locality (part of it or several localities) linked by common needs and interests of life in the neighborhood and acting through various forms of direct participation (assembly, public deliberation, survey, activities through their representatives, communitybased organizations, etc.) with the aim of meeting these needs and interests.

- "Community-based organization" - means an association the founders and members of which are residents (their representatives) of the community of a locality (part of it or several localities) and the purpose of which is to fulfil through initiatives public interests relating to life in the neighborhood.

Social sciences representatives view the "need for community" and the importance of place in people's lives as major concerns. For example, Gieryn [10] suggests defining place as not only the built environment, but also the ways in which those structures are "interpreted, narrated, perceived, felt, understood, and imagined" [33].

Characteristics of Urban Community: As this research focuses on urban community, it is important to distinguish its specific characteristics compared to a rural community. Usually, the number of members in urban communities is significantly higher; structure of local economy is based more on services, industry and trades; the level of education of members is higher, their state of health is better, life expectancy - higher; multiculturalism prevails; there is more intensive movement of people and resources within the territory; there are a higher variety and concentration of functions; and, there are more conflicting interests lower solidarity, weaker community ties, and stronger anonymity.

In conclusion, the idea of community is a confusing concept. It encapsulates issues of identity and belonging, similarity and difference, inclusion and exclusion and place, and has to be considered as both a social and spatial system.

The authors of this research offer to extend the traditional perspective towards main actors of community; we suggest that community members can be not only individuals, but organizations (business, public, non-governmental) as well. They all have to be united by the same aim (-s), share similar values, and have a clearly expressed territorial identity. 


\section{Vitality of Urban Community}

This concept "vitality, vital" can be often found in many different contexts. It is a word, used in different daily situations and different professions without paying sufficient attention to its real meaning. Herbert and Dale [11] pay our attention to the definition of vitality in psychology [34]: "Feeling really "alive" is a familiar yet notably variable aspect of human experience. People regularly speak of being particularly alive or invigorated in certain circumstances or following certain events, whereas in other contexts they can feel "dead" or "drained".

The Oxford English Dictionary [40] defines vitality as "the state of being strong and active" and the "power of giving continuance to life". This means that anything that is alive contains vitality. However, it holds within a precondition that vitality should be considered from the point of view of its intensity: being stronger and more active means having more vitality or the opposite - being weaker and less active means less vitality. Merriam-Webster's Dictionary [25] defines „vitality“ as a „lively or energetic" quality, „the power or ability of something to continue to live, be successful, etc.".

According to Kurtus [19], vitality is a state of being when one (individual or any social system) is full of life and energy. It is also the capacity for survival or for the continuation of a meaningful or purposeful existence. Having vitality means one is energetic, lively or forceful. Being vital is essential to well-being (note: the aim of territorial community is individual and social wellbeing!). The author distinguishes three domains of vitality: physical, mental and emotional. Physical vitality means having energy and strength to do things with vigor. This vitality first requires that you are in good health. Physical vitality means that your body parts are effectively supplied with nutrients and oxygen (resources), and you have developed the strength and endurance to allow you to perform physical tasks (seek for the aim) easily. Mental vitality is having a mental energy to think clearly. It is a state of mental alertness and effectiveness. It requires that one is in good mental health such that the brain is functioning properly and perceptions are clear. Emotional vitality is having an up-beat attitude, such that one is happy, at peace, enthusiastic and joyful. To rephrase Kurtus' explanation in the context of any other social system, a "good health" means that all internal system's sub-systems function well and achieve the desired result (aim); "supply of nutrients and oxygen" means all kinds of resources (inputs) necessary for a system to operate; "strength and endurance" means inner motivation and actions while the "task" is the aim for which the system was created.

To summarize - vitality is when one (any social system - individual, group of individuals (organization/ community/state) is full of life and energy to proactively move towards the aim. It is exuberant physical, mental and emotional vigor. It is also the capacity for survival or for the continuation of a meaningful or purposeful existence. Having vitality means one is energetic, lively or forceful and it is essential to well-being.

But: can (urban) communities - social-spatial systems - be "alive", "dead", "drained"? All cities having sufficient number of its users (residents first of all) are 
"alive", yet the intensity/strength of their life (in other words - the level of their vitality) differs significantly. Cities with significant loss of active local population or already havening no residents can be called "dead".

Social sciences perspective: The concept of vital (urban) communities dates back to the 1960s and 1970s, in the early community psychology literature. At this time, community vitality was defined as "the ability of communities to collectively solve problems" [35]. More recently, the concept of community vitality has been used to describe "the presence of institutional linkages and relationships, group and individual interaction, and community membership or social citizenship".

The Canadian Index of Wellbeing [39] describes vital (urban) communities as those that are able to cultivate and marshal strong, active and inclusive relationships between residents, private sector, public sector and civil society organizations in order to create, adapt and thrive in the changing world and thus improve individual and collective wellbeing of citizens. It emphasizes the understanding of community vitality as the capacity to thrive and change in the pursuit of individual and social wellbeing, in ways that are inclusive and respectful of the needs and aspirations of diverse communities.

In general, the (urban) community vitality is the nature and quality of the people and the places around (for ex. the quality of our social connections and relationships) within a city. According to Scott [35], community vitality is a key source of individual and family well-being. Successful or vital communities are those that have the capacity to act together, to develop and deploy resources, in pursuit of their common goals. Benefits (or liabilities) accrue to individuals as well as groups, organizations or communities as a whole. Dale, Ling and Newman [7] suggest another perspective: they consider the vitality of community as a site of resilience, adaptation and innovation in the face of challenges.

The aim of vital community is to meet individual and common needs: "in a vital community people of all generations work together to find the right balance between meeting individual needs and meeting the needs of the community as a whole" [45].

One of the key areas that directly affect vitality of a local community is its local demographic situation. It has been proved that low population density has a negative impact on local social and economic development, reduces the mutual communication among people and enterprises, and increases the per capita cost of service delivery, increases costs of government [18].

Community vitality requires active citizens. Specifically, vitality requires more than responsible citizens; it requires participatory or justice-oriented citizens [44]. Such citizenship requires empowerment of citizens. Empowerment means the "ability of people to gain understanding and control over personal, social, economic, and political forces in order to take action to improve their life situations" [13]. This kind of empowerment occurs in communities, which can be part of the challenge-a rather big part-if a geographic space contains people of like interests but little connection.

A related concept is a civically healthy community defined as: "one in which participatory processes are inclusive and diverse and in which participants have the 
skills, tools, and confidence to contribute meaningfully to the social, economic, and intellectual strengthening of communities" [5].

The vitality of urban community first of all depends on people residing in the city and their potential opportunities to develop individual and social well-being. Jobs, infrastructure, leisure opportunities can be created and well maintained, yet if there will not be enough people who can work here, use this infrastructure and other local opportunities, the place will eventually die. According to Landry [20], urban vitality is the raw power and energy within a city. When focusing and directing it towards a purpose the city becomes vital. Zhou [46] considers social, cultural and economic activities as key indicators of urban vitality. However, this perspective is too narrow, as it lacks the understanding of the role of other urban subsystems (see Fig. 1) in the process of urban development. Kuliesis and Pareigiene [18], analyzing place vitality, mention 3 main indicators of the viability of communities: economic, social-demographic, infrastructure.

To conclude the discussion on vital urban community from the social sciences perspective, we state that the vitality of urban community appears when members of the territorial community through collaborative action and shared values gain the capacity/ability to provide necessary resources to achieve individual and social wellbeing of local population to sustain itself in the long-term.

Spatial perspective: Referring to the works of Jacobs [14] and Montgomery [28], urban vitality is mostly related to the public life on the streets, squares and parks and the manner in which the users are able to identify themselves with the places in their neighborhoods. Hereby all activities as defined by Gehl [9] are of relevance so functional activities such as commuting, social activities such as children's play and optional activities such as taking a walk. The manner in which these activities are supported by the built environment determine in a great deal the urban vitality. A city or area is vital if there is a rich choice of interesting places for people to experience throughout the year. Zhou [46] quantified several values that may be of relevance concerning urban vitality: the number of people, businesses and various activities in the built environment. Moreover, vitality of the urban space is often referred to in relation to the infrastructural accessibility; when adequately connected to the infrastructural networks surrounding the city, vitality rises.

In urban planners research the vitality is often discussed in relation to redevelopment and transformation of space. With a higher mix of functions the vitality should increase. Additionally, the same is stated concerning the mix of socialeconomic groups within a city. With a mix of both aspects more facilities become viable to exploit and will therefore be developed, which in turn increases urban vitality [27]. Obviously there is a potential maximum of functions that can be combined. According to Montgomery [28], this maximum is defined by the adaptability of several functions. When separate functions can no longer adapt to each other the resulted tension diminishes urban vitality.

The processes described above begins with the vitality of urban space, which exists in the physical domain that facilitates and defines the interactions in the social 
domain. The interactions in turn effectuate investments, which are part of the economical domain. The author argues that a vital city has not only the ability to facilitate the slow physical spatial transition of the city over time but also keeps it going. Only then can there be an effective and sustainable social-economic relationships between suppliers and users of the city, which in turn conditions an evolution of the urban environment. Nonetheless a vital city is not per se a modern city, planned according the ruling paradigms. It is a city that keeps renewing itself and its users.

The most important elements of community vitality from spatial perspective could be: positive development of urban structure, integration of multifunctional spaces, supporting the existing urban structure which creates specific character of the area, attraction of local inhabitants to activities carried in the territory of the community.

Selezneva [36] adds one more important feature: "Vital city is .... a necessarily mixed-use city. Physical space should be appropriate for creating opportunities for and supporting the socio-cultural and economic dynamics and facilitate their diversification".

It could be generalized that from the spatial point of view vital urban community $[2 ; 12]$ has strong spatial identity and expression; it should be large and diverse enough; it must be connected with other parts of urban system; it must have a high degree of spatial integration and spatial-social control and, in many cases, to have a historic continuity. In addition to that, it should have a high degree of redundancy and alternative choices.

\section{Conclusion}

1. Cities compete in the global market of places for resources necessary to assure the success of local socio-economic development. Sufficient and high-quality resources are the main precondition for sustainable well-being of local actors. The key recourse for any city is its people - individuals and their groups. Strong, energetic, safe, vibrant local territorial communities create strong cities. In search for factors facilitating strong and active local (urban) communities, the concepts of "community vitality", "vital community" are becoming more popular.

2. Main characteristics of local communities in cities are: larger number of members; structure of local economy is mainly based on services, industry and trades; the level of education of members is higher, health is better, life expectancy - higher; stronger multiculturalism; more intense movement of people and resources within the territory; higher variety and concentration of functions; more conflicting interests; lower solidarity; weaker community ties; stronger anonymity.

3. Research authors suggest that community members can be not only individuals, but organizations (business, public, non-governmental) as well. They all have to be united by the same aim (-s), values, territory / territorial identity. Thus local urban community is defined as a group of individuals and organizations acting in a defined territory (city or part of it), having common interest in individual and 
social wellbeing and having a sense of shared identity and common values. Looking for possible areas of policy intervention, it is important to comprehended local (urban) community as an open, dynamic social-spatial system. The best results can be achieved only implementing positive interventions into all main subsystems of a city: i.e. social capital, economic, public governance, cultural, built environment, natural. Fragmented efforts to improve just one subsystem ignoring others will not lead to a success.

4. Concept of vital urban community is a complex and difficult to define since each element of the concept encodes several unique meanings as well. However, from the social sciences perspective the vitality of urban community can be identified when members of the territorial community through collaborative action and shared values gain the capacity/ability to provide necessary resources to achieve individual and social well-being of local population to sustain itself in the long-term. From spatial perspective - the vitality of urban community depends on strong spatial identity and expression, sufficient size and diversity, connectivity with other parts of the city, high degree of spatial integration and spatial-social control, historic continuity, high degree of redundancy and alternative choices.

\section{References}

1. Accessibility in Cities: Transport and Urban Form, 2014. NCE Cities Paper 03. LSE Cities. London School of Economics and Political Science. http://newclimateeconomy.report/wp-content/uploads/2014/11/ [2017-01-10].

2. Alexander, Ch., Ishikawa, S., Silverstein, M., Jakobson, M., Fiksdahl-King, I., Angel, S. A Pattern Language. Towns, Buildings, Construction (Center for Environmental Structure Series). New York: Oxford University Press, 1978.

3. Allen, J., Hamnett, C. Introduction. In Allen, J. and Hamnett, C. (eds.). A Shrinking World? Global Unevenness and Inequality. Oxford: Oxford University Press, 1995, p.p. $1-10$.

4. Ansell, Ch., Gash, A. Collaborative Governance in Theory and Practice. Journal of Public Administration Research and Theory, 2007, Vol. 18, p.p. 543-571.

5. Bryer, Th. A. Higher Education beyond Job Creation: Universities, Citizenship, and Community (Reprint Edition). Maryland: Lexington Books, 2014.

6. Cocke, D., Newman, H., Salmons-Rue, J. From the Ground Up. Community-Based Arts Project. New York: Cornell University, 1993.

7. Dale, A., Ling, Ch., Newman L. (2010). Community Vitality: The Role of CommunityLevel Resilience Adaptation and Innovation in Sustainable Development. Sustainability, 2010, Vol. 2, No. 1, p.p. 215-231.

8. European Commission. The URBAN Community Initiative, 2003. http://ec.europa.eu/regional_policy/sources/docgener/presenta/cities/cities_en.pdf [201612-30].

9. Gehl, J. Life Between Buildings: Using Public Space. Washington: Island Press, 2011.

10. Gieryn, T. F. (2000). A Space for Place in Sociology. Annual Review of Sociology, 2000, Vol. 26, pp. 463-496. 
11. Herbert, Y., Dale, A. Community Vitality: The Concept, 2013. https://crcresearch.org/sites/default/files/u641/vitality_-_the_concept.pdf [2016-12-15].

12. Hillier, B. Space Syntax as a Theory as well as a Method. London: University College, 1970 .

13. Israel, B. A., Checkoway, B., Schultz, A., Zimmerman, M. Health Education and Community Empowerment: Conceptualizing and Measuring Perceptions of Individual, Organizational and Community Control. Health Education Quarterly, 1994, Vol. 21, No. 2, p.p. 149-170.

14. Jacobs, J. The Death and Life of Great American Cities. New York: Random House, 1961.

15. Joint Programming Initiative Urban Europe (2016). Global Urban Challenges, Joint European Solutions. http://jpi-urbaneurope.eu/ [2016-12-11].

16. Kirakosyan, L. Understanding 'Community' in “Community Voices”: Implications for Shared Action. http://www.ipg.vt.edu/communityvoices/researchseries/conceptions-ofcommunity.pdf [2016-11-11].

17. Koe, de, D. M. Urban Vitality Through a Mix of Land-uses and Functions: An Addition to Citymaker, 2013. http://edepot.wur.nl/273611 [2016-11-11].

18. Kuliešis, G., Pareigiene, L. Impact of Demographic Factors on Rural Vitality, Lithuanian Institute of Agrarian Economics. Management Theory and Studies for Rural Business and Infrastructure Development, 2014, Vol. 36. No. 1., p.p. 66-73.

19. Kurtus, R. What is Vitality? The School for Champions, 2012. www.school-forchampions.com/vitality/what_is_vitality.htm [2016-11-15].

20. Landry, C. Urban Vitality: A New Source of Urban Competitiveness. Prince Claus Fund Journal, 2000, p.p. 8-13.

21. Landry, Ch. Urban Vitality: A New Source of Urban Competitiveness, 2016. Universidade Federal do Rio de Janeiro. http://www.prourb.fau.ufrj.br/cidades/uheroes/abert/texto3.htm [2016-12-09].

22. Law on Local Self-government of the Republic of Lithuania, 7 July 1994, No. i-533. Last amended on 15 May 2014, No. xii-883. http://www.lithuanialaw.com/lithuanian-law-onself-government-503 [2016-10-20].

23. Lopez Moreno, E., Warah, R. 21st Century Cities: Home to New Riches and Great Misery. UN Chronicle, 2006, Vol. XLIII, No.

24. Mackenzie, A., Dalby, S. Moving Mountains: Community and Resistance in the Isle of Harris, Scotland, and Cape Breton, Canada. Antipode, 2003, Vol. 35, No. 2, p.p. 309333.

25. Merriam-Webster's Dictionary. Vitality definition, 2016. http://www.merriamwebster.com/dictionary/vitality [2016-10-10].

26. Ministry of Finance of the Republic of Lithuania. The National Progress Programme for Lithuania for the period 2014-2020. https://rio.jrc.ec.europa.eu/en/library/nationalprogress-programme-lithuania-period-2014-2020 [2016-11-10].

27. Ministry of Housing Spatial Planning and Environment, The Netherlands. Structuurvisie Randstad 2040: naar een duurzame en concurrerende Europese topregio, 2008. Dan Haag:

Ministry

of

VROM. 
http://ifou.org/summerschool/2009delft/downloads/Randstad_2040_Structuurvisie.pdf [2016-11-20].

28. Montgomery, J. (1998). Making a City: Urbanity, Vitality and Urban Design. Journal of Urban Design, 1998, Vol. 3, No. 1., p.p. 93-116.

29. Nefas, S. Functional Local Community in Lithuanian Towns and Villages, 2007. Mykolas Romeris University, Vilnius. http://vds000004.hosto.lt/safeplaces/wpcontent/uploads/2015/01/Funkcionali-vietos-bendruomene.-Saulius-Nefas.pdf [2016-1105].

30. Open Progress Forum. Lithuania 2030. Vilnius, 2013. http://lietuva2030.1t/old/images/stories/programa.pdf [2016-10-20].

31. Open Progress Forum. Local Communities: Do We Want, Are We Able and Can We Act? Vilnius, 2012. http://lietuva2030.1t/old/images/stories/programa.pdf [2016-10-20].

32. Phillipson, C., Thompson, P. Whither Community Studies? A Special Issue on Researching Community Studies, Past and Present. International Journal of Social Research Methodology, 2008, Vol. 11, No. 2, p.p. 87-91

33. Rode, P., Floater, G., Thomopoulos, N., Docherty, J., Schwinger, P., Mahendra, A., Fang, W. Accessibility in Cities: Transport and Urban Form. The New Climate Economy, 2014. https://files.lsecities.net/files/2014/11/LSE-Cities-2014-Transport-and-UrbanForm-NCE-Cities-Paper-03.pdf [2016-10-10].

34. Ryan, R., Frederick, C. (1997). On Energy, Personality, and Health: Subjective Vitality as a Dynamic Reflection of Well-being. Journal of Personality, 1997, Vol. 65, No. 3, p.p. $529-565$.

35. Scott, K. Community Vitality: Measuring What Matters, 2009. http://www.communityvitality.com.au/wpcontent/uploads/2013/07/Community_Vitality_Measuring.pdf [2016-12-15].

36. Selezneva, E. (2011). Urban Vitality: Exploring the Centrality Conditions. file://C:/Users/jurgita/Downloads/FinalThesis_Selezneva2011.pdf [2016-10-10].

37. Staheli, L., Thompson, A. Citizenship, Community and Struggles for Public Space. The Professional Geographer, 1997, Vol. 49, p.p. 28-38.

38. State Progress Council, 2010. Lithuania's Progress Strategy "Lithuania 2030" https://lrv.lt/uploads/main/documents/files/EN_version/Useful_information/lithuania203 $0 . p d f$ [2016-12-15].

39. The Canadian Index of Wellbeing, 2010. Community Vitality: Report of the Canadian Index of Wellbeing. http://www.unesco.org/fileadmin/MULTIMEDIA/HQ/CLT/pdf/communityvitalitydomai nreport.pdf [2017-01-10].

40. The Oxford English Dictionary, 2016. Vitality. Community. https://en.oxforddictionaries.com/definition/vitality [2016-11-11].

41. Ulibarri, N., Scott, T. A. Linking Network Structure to Collaborative Governance. Journal of Public Administration Research and Theory, 2016, Vol. 27, No. 1, p.p. 163181.

42. United Nations Human Settlements Programme (UN-Habitat). Urban Patterns for a Green Economy Working with Nature. 
43. Vaitkus, E. A Strong Community - an Example of Citizenship. Virsuliskes Local Community, 2014. Vilnius City Municipality. http://www.bendruomenes.lt/svetaine/virsuliskes/komentarai/stipri_bendruomene_pilietis kumo_pavyzdys [2016-11-11].

44. Westheimer, J., Kahne, J. What Kind of Citizen: The Politics of Educating for Democracy. American Educational Research Journal, 2004, Vol. 41, No., 2, p.p. 237 269.

45. What's Needed for a Vital Community? Vital Aging Network, 2011. http://www.vitalagingnetwork.org/Vital_Communities_Toolkit/31/What_s_Needed_for_a_Vital_Community_. html.

46. Zhou, J. (2012). Urban Vitality in Dutch and Chinese New Towns: A Comparative Study $\begin{array}{llll}\text { between Almere and } & \text { Tongzhou, }\end{array}$ http://repository.tudelft.nl/islandora/object/uuid:d0781200-1e73-4b29-a451-

219f3adf3a08? collection=research [2016-11-11].

Jolita Sinkiene, Egle Gaule, Jurgita Bruneckiene, Kestutis Zaleckis, Thomas A. Bryer, Evaldas Ramanauskas

\section{Tarpdisciplininis požiūris ị miesto bendruomenių gyvybingumo tyrimus}

\section{Anotacija}

Miestų vystymosi sèkmę lemia ne tik jų politinè ar ekonominė galia, išplètota infrastruktūra ar palanki geografinè padètis. Svarbiausias sėkmès veiksnys yra mieste gyvenantys žmonès ir jų gebẻjimas bendradarbiaujant proaktyviai reaguoti ì šiuolaikinių miestų vystymosi iššūkius. Demokratinèse visuomenèse miesto vietos bendruomenès yra pačios svarbiausios jo sandaros ląstelès sąlygojančios viso miesto gyvybę ir taip užtikrinančios tvarų ir darnų vystymąsi. Nors politinèse darbotvarkèse ir mokslininkų tyrimuose (miesto) bendruomenių gyvybingumo sąvoka vartojama vis intensyviau, tačiau pasigendama suderintos ir moksliškai pagrịstos šios koncepcijos turinio apibrěžties bei jos raiškos tyrimų metodologijos. Šiame straipsnyje pagrindžiamas miesto bendruomenès gyvybingumo aktualumas miesto vystymuisi, išryškinamos šios koncepcijos turinio interpretacijos skirtingu mokslų perspektyvoje, pateikiama miesto bendruomenès gyvybingumo koncepcija. Šiame straipsnyje pristatoma dalis platesnio grupès mokslininkų tyrimo, kuriuo buvo siekiama parengti miesto bendruomenès gyvybingumo tyrimo metodologiją, rezultatų.

Jolita Sinkiene is an Associate Professor in the Institute of Public Policy and Administration, Faculty of Social Sciences, Arts and Humanities at Kaunas University of Technology.

E-mail.: jolita.sinkiene@ktu.lt.

Egle Gaule is an Associate Professor in the Institute of Public Policy and Administration, Faculty of Social Sciences, Arts and Humanities at Kaunas University of Technology.

E-mail.: egle.gaule@ktu.lt. 
Jurgita Bruneckiene is an Associate Professor in the Department of Economics, Faculty of Economics and Business at Kaunas University of Technology.

E-mail.: jurgita.bruneckiene@ ktu.lt.

Kęstutis Zaleckis is a Professor of the Department of Architecture and Urbanism, Faculty of Civil Engineering and Architecture, Kaunas University of Technology.

E-mail.: kestutis.zaleckis@ktu.lt.

Thomas A. Bryer is an Associate Professor of the School of Public Administration, University of Central Florida and a Chief Researcher and Fulbright Core Scholar at Kaunas University of Technology.

E-mail.: thomas.bryer@ucf.edu.

Evaldas Ramanauskas is an Associate Professor of the Institute of Architecture and Construction, Kaunas University of Technology.

E-mail.: evaldas.ramanauskas@ktu.lt.

Jolita Sinkiené yra Kauno technologijos universiteto, Socialinių, humanitariniu mokslų ir menų fakulteto, Viešosios politikos ir administravimo instituto docente.

E.paštas: jolita.sinkiene@ ktu.lt.

Egle Gaule yra Kauno technologijos universiteto, Socialinių, humanitarinių mokslų ir menų fakulteto, Viešosios politikos ir administravimo instituto docentė.

E.paštas: egle.gaule@ktu.lt.

Jurgita Bruneckiené yra Kauno technologijos universiteto, Ekonomikos ir verslo fakulteto, Ekonomikos katedros docentè.

E.paštas: jurgita.bruneckiene@ktu.lt.

Kęstutis Zaleckis yra Kauno technologijos universiteto, Statybos ir architektūros fakulteto, Architektūros ir urbanistikos katedros profesorius.

E.paštas: kestutis.zaleckis@ktu.lt.

Thomas A. Bryer yra Centrinès Floridos universiteto, Viešojo administravimo mokyklos docentas ir Kauno technologijos universiteto vyriausiasis mokslo darbuotojas, besistažuojantis pagal Fulbright programą.

E.paštas: thomas.bryer@ucf.edu.

Evaldas Ramanauskas yra Kauno technologijos universiteto, Architektūros ir statybos instituto docentas.

E.paštas: evaldas.ramanauskas@ktu.lt.

Straipsnis įteiktas redakcijai 2017 m. vasario mèn.; recenzuotas; parengtas spaudai 2017 m. kovo mèn. 